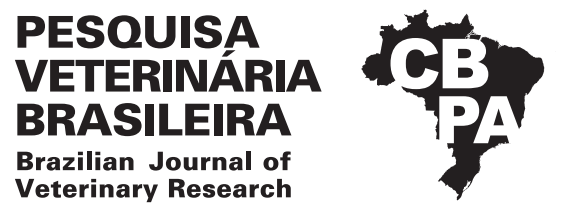

Pesq. Vet. Bras. 39(9):757-763, September 2019 DOI: 10.1590/1678-5150-PVB-6200

Original Article

ISSN 0100-736X (Print)

ISSN 1678-5150 (Online)

\title{
Antimicrobial susceptibility and minimal inhibitory concentration of bacteria isolated from the eyes of dogs with keratoconjunctivitis sicca ${ }^{1}$
}

\author{
Carolina S.G. Pereira ${ }^{2}$, Luís Felipe C. Zulim² ${ }^{2}$ Rogério Giuffrida² ${ }^{2}$ Aline G. Cruz ${ }^{3}$, \\ Bruna T.D. Foglia ${ }^{3}$, Hugo Benguella ${ }^{3}$, Aline S. Batista ${ }^{4}$ and Silvia F. Andrade ${ }^{5 *}$ (D)
}

\begin{abstract}
Pereira C.S.G., Zulim L.F.C., Giuffrida R., Cruz A.G., Foglia B.T.D., Benguella H., Batista A.S. \& Andrade S.F. 2019. Antimicrobial susceptibility and minimal inhibitory concentration of bacteria isolated from the eyes of dogs with keratoconjunctivitis sicca. Pesquisa Veterinária Brasileira 39(9):757-763. Departamento de Clínica Médica de Pequenos Animais, Hospital Veterinário, Universidade do Oeste Paulista, Rod. Raposos Tavares Km 572, Presidente Prudente, SP 19067-175, Brazil. E-mail: silviafranco@unoeste.br

The objective of this study was to evaluate the antimicrobial susceptibility profile of bacteria isolated from the eyes of dogs with keratoconjunctivitis sicca (KCS). We evaluated 65 dogs diagnosed with KCS and 30 healthy dogs (Control Group). Conjunctival swab samples were collected after KCS was diagnosed. Microbiological examinations were performed, including aerobic culture, antimicrobial susceptibility testing and minimum inhibitory concentration (MIC) determination for chloramphenicol, tobramycin, ofloxacin and moxifloxacin. MICs of the fifteen most resistant strains of Staphylococcus pseudintermedius (Staphylococcus intermedius Group, SIG) and the fifteen most resistant strains of gram-negative bacteria were determined. By percentage, the microorganisms exhibited the highest susceptibility to polymyxin B, tobramycin and chloramphenicol and the lowest to tetracycline. Three multi-drug-resistant strains of SIG were detected: one displayed isolated susceptibility to cefazolin, another to vancomycin, and another to polymyxin B and amikacin. The species of bacteria isolated from the eyes of dogs with KCS presented variable susceptibility to the antibiotics tested. We found evidence of the emergence of quinolone-resistant strains of SIG and further evidence of increased ocular prevalence. These findings reinforce the need to identify the bacteria involved and their antimicrobial susceptibility profile, as secondary infections can serve as exacerbating and perpetuating factors in KCS.
\end{abstract}

INDEX TERMS: Antimicrobial susceptibility, testing, disk diffusion, bacteria, dogs, eyes, keratoconjunctivitis sicca, bacterioses.

RESUMO.- [Susceptibilidade antimicrobiana e concentração inibitória mínima de bactérias isoladas dos olhos de cães com ceratoconjuntivite seca.] 0 objetivo deste estudo

\footnotetext{
${ }^{1}$ Received on April 10, 2019.

Accepted for publication on May 7, 2019.

${ }^{2}$ Graduate Studies Program in Animal Science, Universidade do Oeste Paulista (Unoeste), Rod. Raposo Tavares Km 572, Presidente Prudente, SP 19067-175, Brazil.

${ }^{3}$ Faculdade de Medicina Veterinária, Universidade do Oeste Paulista (Unoeste), Rod. Raposo Tavares Km 572, Presidente Prudente, SP 19067-175.

${ }^{4}$ Residente do Laboratório de Patologia Clínica, Hospital Veterinário, Universidade do Oeste Paulista (Unoeste), Rod. Raposo Tavares Km 572, Presidente Prudente, SP 19067-175.

${ }^{5}$ Departamento de Clínica Médica de Pequenos Animais, Hospital Veterinário, Universidade do Oeste Paulista (Unoeste), Rod. Raposos Tavares Km 572, Presidente Prudente, SP 19067-175. *Correspondig author: silviafranco@unoeste.br
}

foi avaliar o perfil de susceptibilidade antimicrobiana de bactérias isoladas de olhos de cães com ceratoconjuntivite seca (CCS). Foram avaliados 65 cães com diagnóstico de CCS e 30 cães saudáveis (Grupo Controle). Depois do diagnosticado de CCS, suabes conjuntivais foram coletados. Exames microbiológicos foram realizados, incluindo cultura aeróbia, teste de susceptibilidade antimicrobiana e determinação da concentração inibitória mínima (CIM) para cloranfenicol, tobramicina, ofloxacina e moxifloxacina. Para determinar a CIM, foram selecionadas as quinze cepas mais resistentes de Staphylococcus pseudintermedius (Staphylococcus intermedius Group-SIG) e as quinze cepas mais resistentes de bactérias gram-negativas. Os microrganismos apresentaram maior suscetibilidade percentual à polimixina $B$, tobramicina e cloranfenicol e menor suscetibilidade à tetraciclina. 
Três cepas de SIG resistentes a múltiplos medicamentos foram detectadas, do quais um demonstrou suscetibilidade isolada à cefazolina, outro à vancomicina e outro à polimixina B e à amicacina. As espécies de bactérias isoladas dos olhos de cães com CCS apresentaram suscetibilidade variável aos antibióticos testados. Encontramos evidências do surgimento de cepas resistentes à quinolona de $S$. pseudintermedius e outras evidências de aumento da prevalência ocular. Esses achados reforçam a necessidade de identificar as bactérias envolvidas e seu perfil de susceptibilidade aos antimicrobianos, pois as infecções secundárias podem servir como fatores exacerbantes e perpetuantes na CCS.

TERMOS DE INDEXAÇÃO: Susceptibilidade antimicrobiana, concentração inibitória mínima, bactérias, olhos, cães, ceratoconjuntivite seca, caninos, bacterioses.

\section{INTRODUCTION}

Keratoconjunctivitis sicca (KCS), or dry eye, is a common ophthalmopathy that usually occurs in dogs and humans due to a deficiency in the aqueous component of the pre-corneal tear film or to modified quality of and/or reduction in tear stability. KCS has multiple etiologies, and the most prevalent involves immunomediation (Carter \& Colitz 2002, Williams 2008, McGinnigle et al. 2012, Stevenson et al. 2012, Giuliano 2013, Messmer 2015).

Topical therapy for keratoconjunctivitis sicca generally consists of immunosuppressants, such as cyclosporine, tacrolimus or pimecrolimus, and lachrymal substitutes, which are combined with antibiotics for the treatment of secondary infections. Typical antibiotics include gentamicin, tobramycin, chloramphenicol, ofloxacin, moxifloxacin, and gatifloxacin. In addition, topical anti-inflammatory agents, mucolytics and parasympathomimetic stimulants of lacrimal secretion may be used (Wilkie 1996, Carter \& Colitz 2002, Miller 2008, Giuliano 2013, Messmer 2015).

Secondary bacterial infections are common in keratoconjunctivitis sicca (Carter \& Colitz 2002, Messmer 2015, Leigue et al. 2016). In general the ocular surface is colonized by commensal bacteria that, together with humoral factors, inhibit colonization by pathogenic microorganisms. In healthy dogs, gram-positive bacteria are principally present on the ocular surface. Nonetheless, species profiles vary according to geographical location, technique used to cultivate tear secretions, contact with other animals, population density and season (Armstrong 2000, Prado et al. 2005, Gould \& Papasouliotis 2013).

In eyes with an external injury, superficial inflammation of the cornea and conjunctiva is triggered, leading to a decrease in antibacterial enzymes (lactoferrin, lysozyme and peroxidase). Moreover, the accompanying loss of epithelial integrity, depending on the degree and intensity of the trauma and tear film modifications, favors the colonization of ocular structures by opportunistic bacteria and fungi (Murphy et al. 1978, Mannis \& Smolin 1996, Armstrong 2000).

Microorganisms with a high prevalence in the eyes of healthy dogs include Staphylococcus epidermidis, Staphylococcus pseudintermedius, Staphylococcus aureus, Streptococcus pneumoniae, Escherichia coli, Streptococcus sp., Enterobacter sp., and Pseudomonas aeruginosa (Murphy et al. 1978, Andrade et al. 2002, Prado et al. 2005). In the ocular environment, these microorganisms usually act as opportunists, aggravating the clinical signs of keratoconjunctivitis sicca. Under these circumstances, empiric treatment with eye drops containing high concentrations of antimicrobials such as chloramphenicol, aminoglycosides (neomycin, gentamicin, tobramycin), tetracyclines, second-generation (ofloxacin, ciprofloxacin) and fourth-generation (gatifloxacin and moxifloxacin) quinolones are indicated (Lin \& Petersen-Jones 2007, Quinn et al. 2011, Gould \& Papasouliotis 2013, Mello et al. 2017). However, the efficacy of topical therapy may be influenced by several factors, including antimicrobial resistance of the microorganisms involved, insufficient penetration of the antimicrobial into the inner areas of the eye (vitreous humor), co-infection with fungal microorganisms, changes in microorganism profiles during treatment and immune-debilitating conditions (Hendrix \& Cox 2008, Kaye et al. 2010, Ahn et al. 2011).

Some studies have suggested that in vitro susceptibility may predict clinical outcome in humans with bacterial keratitis (Kaye et al. 2010, Lalitha et al. 2012). To date, determination of the minimum inhibitory concentration (MIC), which corresponds to the lowest antimicrobial concentration capable of inhibiting the development of the bacterium in vitro, is recognized as the most reliable method for selecting antimicrobial drugs to treat eye infections (Andrews 2001, CLSI 2017). Indeed, a recent study reported the MICs of Pseudomonas aeruginosa isolated from septic ocular surface disease in different animal species, and MIC results were used to target antimicrobial therapy strategies, focusing on the concentration and frequency of tobramycin application (Leigue et al. 2016).

The aim of the present study was to evaluate the antimicrobial susceptibility profile of bacteria isolated from the eyes of dogs with keratoconjunctivitis sicca in the region of Presidente Prudente/SP, Brazil.

\section{MATERIALS AND METHODS}

Ethics statement. The study was conducted and approved in accordance with the animal testing regulations of the Ethics Committee on Animal Use (CEUA) of Unoeste (Protocol no. 1802 and 1803) and was in accordance with the rules of the ARVO (Association for Research in Vision and Ophthalmology - Statement for the use of animals in ophthalmic and visual research).

Animals. This study was conducted at the Veterinary Hospital of the Unoeste, Presidente Prudente/SP, from 2014 to 2017. We evaluated 65 dogs (130 eyes) diagnosed with keratoconjunctivitis sicca; 36 (55\%) were female, and 29 (45\%) were male, with a mean age of $7.1 \pm 3.9$ years old and a mean weight of $10.4 \pm 7.5 \mathrm{~kg}$. The most common breeds were Lhasa Apso and mixed breeds, with 17 (26.2\%) dogs each, followed by 10 Poodles (15.4\%), 5 Pinschers $(7.7 \%)$, 3 Yorkshire Terriers (4.6\%), 2 Pit Bulls (3.1\%) and 11 other breeds $(1.5 \%)$. The dogs were registered through an authorization form (Term of Free and Informed Consent) signed by the owners and those responsible for the project. The control group consisted of 30 healthy dogs ( 60 eyes) without ocular problems from the kennel of Unoeste institution; 17 (56.6\%) were female, and 13 (43.4\%) were male, with a mean age of $4.3 \pm 3.0$ years old and a mean weight of $18.1 \pm 12.7 \mathrm{~kg}$. The breeds of the control group were $24(80 \%)$ mixed breed, 5 (16.7\%) Boxer and 1 (3.3\%) Labrador Retriever.

Ophthalmic exams. All animals were evaluated using ophthalmic exams: biomicroscopy slit-lamp examination (Kowa SL-17 portable slit lamp, Japan), Schirmer tear test 1 (STT-1) (Teste de Schirmer, Ophthalmos, São Paulo, Brazil), fluorescein test (FT) (Flouresceína 
Strips, Ophthalmos, São Paulo, Brazil), tear film break-up time (TBUT), and applanation tonometry (Tono-Pen, USA). The diagnosis of KCS was based on clinical signs (conjunctival hyperemia, ocular discharge and presence of corneal opacity, ulcer, vascularization or pigmentation) and specific ophthalmic tests that included STT-1 (values $\leq 15 \mathrm{~mm} / \mathrm{min}$ ) and/or TBUT ( $\leq 25$ seconds) (Maggs 2008). Only dogs with keratoconjunctivitis sicca and no history of having received systemic or topical antibiotics in the preceding 30 days were included in the study.

Microbiological methods. After keratoconjunctivitis sicca was diagnosed, samples of ocular secretions were collected from the lower conjunctivae of both eyes using sterile cotton swabs, which were used to inoculate Petri dishes containing 5\% defibrinated bovine blood agar and MacConkey agar. The inoculated plates were incubated under aerobic conditions at $37^{\circ} \mathrm{C}$ for $24-48$ hours. Isolated bacterial colonies were classified according to morphology, staining and biochemical characteristics. Only strains isolated from dogs with KCS were tested for antimicrobial susceptibility. Initially, the isolates for susceptibility testing were seeded in brain-heart infusion broth and incubated at $37^{\circ} \mathrm{C}$ for $24-48$ hours under aerobic conditions. After this period, the broths were diluted with saline until reaching a turbidity of 0.5 on the McFarland scale. A sterile cotton-wool swab was dipped into the suspension, and excess liquid was removed by rotating the swab against the side of the container. The inoculum was then spread evenly over the entire surface of a plate by swabbing in five directions (Quinn et al. 2011).

After the 30-minute period necessary for inoculum absorption, filter-paper disks (Cecon, São Paulo, Brazil) were deposited evenly over the agar surface. These disks contained the following antibacterial agents: cefazolin $(30 \mathrm{mcg})$, ciprofloxacin $(5 \mathrm{mcg})$, chloramphenicol (30 mcg), gentamicin (10 mcg), neomycin (30 mcg), norfloxacin (10 mcg), ofloxacin $(5 \mathrm{mcg})$, polymyxin B $(300 \mathrm{mcg})$, tetracycline $(30 \mathrm{mcg})$, tobramycin $(10 \mathrm{mcg})$ and vancomycin $(30 \mathrm{mcg})$. After 18 hours of incubation, the diameters of the inhibition zones around the disks were measured with a caliper, and the results, expressed in millimeters, were compared to international standards for the interpretation of results (CLSI 2017). For drugs without criteria for dogs, standards of interpretation indicated for humans were used.

The MICs of the most relevant and potentially pathogenic isolates for dogs were evaluated for sensitivity to chloramphenicol, tobramycin, ofloxacin and moxifloxacin through the cutoffs by the E-test method (Probac, São Paulo, Brazil). One aliquot of the broth was seeded superficially onto Mueller-Hinton agar plates using a sterile swab. After 30 minutes, commercial plastic strips impregnated with chloramphenicol $(0.016-256 \mu \mathrm{g} / \mathrm{mL})$, tobramycin $(0.064-1024 \mu \mathrm{g} / \mathrm{mL})$, or ofloxacin and moxifloxacin $(0.002-32 \mu \mathrm{g} / \mathrm{mL})$ were deposited onto the agar surface. After incubation at $37^{\circ} \mathrm{C}$ for 24 hours, the observed points of growth inhibition corresponding to the MICs were computed for each agent. The patterns observed were compared with the breakpoints established by the Clinical and Laboratory Standards Institute (CLSI 2017) to classify isolates as susceptible, partially susceptible or resistant. Given that CLSI (2017) has no cutoff for moxifloxacin, we adopted the breakpoints recommended by Eucast. Cutoff points for susceptibility were as follows: chloramphenicol, $\mathrm{S} \leq 8 \mu \mathrm{g} / \mathrm{mL}$; moxifloxacin, $\mathrm{S} \leq 0.25 \mu \mathrm{g} / \mathrm{mL}$; ofloxacin, $S \leq 1 \mu \mathrm{g} / \mathrm{mL}$; and tobramycin $S \leq 4 \mu \mathrm{g} / \mathrm{mL}$. The cutoff points for gram-negative bacteria (Enterobacteriaceae) were as follows: chloramphenicol, $\mathrm{S} \leq 8 \mu \mathrm{g} / \mathrm{mL}$; moxifloxacin, $\mathrm{S} \leq 0.5 \mu \mathrm{g} / \mathrm{mL}$; ofloxacin, $\mathrm{S} \leq 1 \mu \mathrm{g} / \mathrm{mL}$; and tobramycin, $\mathrm{S} \leq 4 \mu \mathrm{g} / \mathrm{mL}$.

Statistical analysis. The prevalence of positive ocular culture was determined for both the dogs with keratoconjunctivitis sicca and those in the control group using 95\% confidence intervals (CIs). The positivity percentages of dogs in the KCS and control groups were compared using the binomial test for proportions. The significance level used in all tests was $5 \%$. The categorical concordance index was calculated to evaluate agreement between the results that classified the isolates as sensitive and resistant.

\section{RESULTS}

In the group of animals with keratoconjunctivitis sicca, 59 of the 65 dogs $(90.8 \%, 95 \% \mathrm{CI}=83.7-97.8 \%)$ were positive by culture for at least one eye. In the control group, 11 of the 30 dogs $(36.7 \%, 95 \%$ CI = 19.4-53.9\%) were culture positive for at least one eye. These percentages were significantly different between the control and KCS groups ( $\mathrm{p}<0.0001)$.

All isolates from the control group were classified as Staphylococcus pseudintermedius. However, because this species presents phenotypic and genotypic similarities with species of the complex 'Staphylococcus intermedius Group (SIG)', we chose to call it "SIG" (Mališová et al. 2019). For animals with keratoconjunctivitis sicca, the microbiological profile consisted of both gram-positive and gram-negative species (Table 1). A total of $7.5 \%$ of the microorganisms were isolated from only one eye, whereas $92.4 \%$ were found in both eyes. Discordance between the microbiological results for the right and left eyes was observed in $44(67.7 \%)$ of the 65 dogs with KCS.

The susceptibility based on the disk-diffusion method of the agents isolated is described in Table 2. To determine MICs through the E-test method, fifteen SIG strains and fifteen gram-negative strains (eleven Escherichia coli, three Enterobacter aerogenes and one Citrobacter freundii) were selected (Table 3). High agreement was verified between the disk-diffusion and E-test methods for chloramphenicol, good agreement for ofloxacin and weak agreement for tobramycin (Table 4).

SIG strains exhibiting multi-drug resistance were detected in $3(4.6 \%)$ of the 65 dogs with keratoconjunctivitis sicca; this was defined as resistance to nine or more principal antimicrobials. These isolates were subjected to new susceptibility tests, which revealed that one isolate was susceptible to cefazolin, one was susceptible to vancomycin, and one was susceptible to polymyxin B and amikacin. Due to the absence of suitable commercial preparations in Brazil,

Table 1. Microorganisms isolated from ocular secretions from both eyes of dogs $(n=65)$ with KCS

\begin{tabular}{lc}
\hline \multicolumn{1}{c}{ Microorganism } & Total (\%) \\
\hline Burkholderia cepacia & $1(0.8)$ \\
Citrobacter freundii & $1(0.8)$ \\
Corynebacterium sp. & $1(0.8)$ \\
Enterobacter gergoviae & $1(0.8)$ \\
Klebsiella pneumoniae & $1(0.8)$ \\
Serratia sp. & $1(0.8)$ \\
Proteus mirabilis & $2(1.5)$ \\
Pseudomonas aeruginosa & $3(2.3)$ \\
Enterobacter aerogenes & $4(3.0)$ \\
Escherichia coli & $14(10.6)$ \\
Streptococcus sp. & $15(11.4)$ \\
Staphylococcus pseudintermedius & $88(66.7)$ \\
TOTAL & $132(100)$
\end{tabular}


Table 2. Proportion susceptible to antimicrobial drug using the disk diffusion method

\begin{tabular}{|c|c|c|c|c|c|c|c|c|c|c|}
\hline \multirow{3}{*}{ Microorganism } & \multicolumn{10}{|c|}{ Susceptibility } \\
\hline & $\mathrm{Cfz}$ & Cip & Clo & Gen & Neo & Nor & Ofx & Pol B & Tet & Tob \\
\hline & $\mathrm{n}=60$ & $\mathrm{n}=132$ & $\mathrm{n}=132$ & $\mathrm{n}=132$ & $\mathrm{n}=132$ & $\mathrm{n}=132$ & $\mathrm{n}=132$ & $\mathrm{n}=72$ & $\mathrm{n}=132$ & $\mathrm{n}=132$ \\
\hline Burkholderia cepacia & $\begin{array}{c}1 / 1 \\
(100 \%)\end{array}$ & $\begin{array}{c}1 / 1 \\
(100 \%)\end{array}$ & $\begin{array}{c}1 / 1 \\
(100 \%)\end{array}$ & $\begin{array}{c}1 / 1 \\
(100 \%)\end{array}$ & $\begin{array}{c}1 / 1 \\
(100 \%)\end{array}$ & $\begin{array}{c}1 / 1 \\
(100 \%)\end{array}$ & $\begin{array}{c}1 / 1 \\
(100 \%)\end{array}$ & $\mathrm{Nt}$ & $\begin{array}{c}1 / 1 \\
(100 \%)\end{array}$ & $\begin{array}{c}1 / 1 \\
(100 \%)\end{array}$ \\
\hline Corynebacterium sp. & $\begin{array}{c}1 / 1 \\
(100 \%)\end{array}$ & $0 / 1(0 \%)$ & $\begin{array}{c}1 / 1 \\
(100 \%)\end{array}$ & $\begin{array}{c}1 / 1 \\
(100 \%)\end{array}$ & $\begin{array}{c}1 / 1 \\
(100 \%)\end{array}$ & $0 / 1(0 \%)$ & $0 / 1(0 \%)$ & $\mathrm{Nt}$ & $0 / 1(0 \%)$ & $\begin{array}{c}1 / 1 \\
(100 \%)\end{array}$ \\
\hline Pseudomonas aeruginosa & $\begin{array}{c}3 / 3 \\
(100 \%)\end{array}$ & $\begin{array}{c}3 / 3 \\
(100 \%)\end{array}$ & $0 / 3(0 \%)$ & $\begin{array}{c}3 / 3 \\
(100 \%)\end{array}$ & $0 / 3(0 \%)$ & $\begin{array}{c}3 / 3 \\
(100 \%)\end{array}$ & $\begin{array}{c}3 / 3 \\
(100 \%)\end{array}$ & $\mathrm{Nt}$ & $0 / 3(0 \%)$ & $\begin{array}{c}3 / 3 \\
(100 \%)\end{array}$ \\
\hline Enterobacteriaceae & $\begin{array}{c}10 / 12 \\
(83.3 \%)\end{array}$ & $\begin{array}{c}14 / 24 \\
(58.3 \%)\end{array}$ & $\begin{array}{c}19 / 24 \\
(79.2 \%)\end{array}$ & $\begin{array}{c}15 / 24 \\
(62.5 \%)\end{array}$ & $\begin{array}{c}11 / 24 \\
(45.8 \%)\end{array}$ & $\begin{array}{c}17 / 24 \\
(70.8 \%)\end{array}$ & $\begin{array}{c}20 / 24 \\
(83.3 \%)\end{array}$ & $\begin{array}{c}13 / 13 \\
(100 \%)\end{array}$ & $\begin{array}{c}11 / 24 \\
(45.8 \%)\end{array}$ & $\begin{array}{c}16 / 24 \\
(66.7 \%)\end{array}$ \\
\hline Staphylococcus spp. & $\begin{array}{c}20 / 31 \\
(64.5 \%)\end{array}$ & $\begin{array}{c}55 / 88 \\
(62.5 \%)\end{array}$ & $\begin{array}{c}80 / 88 \\
(90.9 \%)\end{array}$ & $\begin{array}{c}70 / 88 \\
(79.5 \%)\end{array}$ & $\begin{array}{c}56 / 88 \\
(63.6 \%)\end{array}$ & $\begin{array}{c}61 / 88 \\
(69.3 \%)\end{array}$ & $\begin{array}{l}58 / 88 \\
(65.9)\end{array}$ & $\begin{array}{c}57 / 58 \\
(98.3 \%)\end{array}$ & $\begin{array}{c}34 / 88 \\
(38.6 \%)\end{array}$ & $\begin{array}{c}76 / 88 \\
(86.4 \%)\end{array}$ \\
\hline Streptococcus spp. & $\begin{array}{c}8 / 12 \\
(66.7 \%)\end{array}$ & $\begin{array}{c}8 / 15 \\
(53.3 \%)\end{array}$ & $\begin{array}{c}7 / 15 \\
(46.7 \%)\end{array}$ & $\begin{array}{c}14 / 15 \\
(93.3 \%)\end{array}$ & $\begin{array}{c}5 / 15 \\
(33.3 \%)\end{array}$ & $\begin{array}{c}13 / 15 \\
(86.7 \%)\end{array}$ & $\begin{array}{c}14 / 15 \\
(93.3 \%)\end{array}$ & $\begin{array}{c}1 / 1 \\
(100 \%)\end{array}$ & $\begin{array}{c}7 / 15 \\
(46.7 \%)\end{array}$ & $\begin{array}{c}10 / 15 \\
(66.7 \%)\end{array}$ \\
\hline
\end{tabular}

$\mathrm{Cfz}=$ cefazolin, Cip = ciprofloxacin, Clo $=$ chloramphenicol, Gen = gentamicin, Neo $=$ neomycin, Nor $=$ norfloxacin, $\mathrm{Nt}=$ not tested, Ofx $=$ ofloxacin Pol B = polymyxin B, Tet = tetracycline, Tob = tobramycin .

Table 3. Sensitivity of microorganisms to the antibiotics using the E-test method

\begin{tabular}{|c|c|c|c|c|c|c|c|c|}
\hline \multirow{3}{*}{$\begin{array}{c}\text { Concentration } \\
\mu \mathrm{g} / \mathrm{mL}\end{array}$} & \multicolumn{8}{|c|}{ Antimicrobial } \\
\hline & \multicolumn{4}{|c|}{ Staphylococcus pseudintermedius $(\mathrm{n}=15)$} & \multicolumn{4}{|c|}{ Gram-negative (Enterobacteriaceae) $(n=15)$} \\
\hline & Clo & Mox & Ofx & Tob & Clo & Mox & Ofx & Tob \\
\hline 0.016 & $0 / 15(0 \%)$ & $0 / 15(0 \%)$ & $0 / 15(0 \%)$ & $0 / 15(0 \%)$ & $0 / 15(0 \%)$ & $1 / 15(6.7 \%)$ & $0 / 15(0 \%)$ & $0 / 15(0 \%)$ \\
\hline$\leq 0.064$ & $0 / 15(0 \%)$ & $0 / 15(0 \%)$ & $0 / 15(0 \%)$ & 1/15 (6.7\%) & $0 / 15(0 \%)$ & $4 / 15(26.7 \%)$ & $1 / 15(6.7 \%)$ & $0 / 15(0 \%)$ \\
\hline 0.094 & $0 / 15(0 \%)$ & $0 / 15(0 \%)$ & $0 / 15(0 \%)$ & 1/15 (6.7\%) & $0 / 15(0 \%)$ & $1 / 15(6.7 \%)$ & $2 / 15(13.3 \%)$ & $0 / 15(0 \%)$ \\
\hline 0.25 & $0 / 15(0 \%)$ & $0 / 15(0 \%)$ & $0 / 15(0 \%)$ & $0 / 15(0 \%)$ & $0 / 15(0 \%)$ & $1 / 15(6.7 .6 \%)$ & $2 / 15$ (13.3\%) & $1 / 15(6.7 \%)$ \\
\hline 0.38 & $0 / 15(0 \%)$ & $0 / 15(0 \%)$ & 2/15 (13.3\%) & $0 / 15(0 \%)$ & $0 / 15(0 \%)$ & $0 / 15(0 \%)$ & $1 / 15$ (6.7\%) & $4 / 15(26.7 \%)$ \\
\hline 0.50 & $0 / 15(0 \%)$ & $0 / 15(0 \%)$ & $0 / 15(0 \%)$ & $0 / 15(0 \%)$ & $0 / 15(0 \%)$ & $1 / 15(6.7 \%)$ & $0 / 15(0 \%)$ & $6 / 15(40 \%)$ \\
\hline 0.75 & $0 / 15(0 \%)$ & $0 / 15(0 \%)$ & $1 / 15(6.7 \%)$ & $0 / 15(0 \%)$ & $0 / 15(0 \%)$ & $0 / 15(0 \%)$ & $1 / 15$ (6.7\%) & $3 / 15$ (20\%) \\
\hline 1.0 & $0 / 15(0 \%)$ & $0 / 15(0 \%)$ & $0 / 15(0 \%)$ & 1/15 (6.7\%) & $1 / 15$ (3.3\%) & $0 / 15(0 \%)$ & $1 / 15(3.3 \%)$ & $0 / 15(0 \%)$ \\
\hline 6 & $0 / 15(0 \%)$ & $0 / 15(0 \%)$ & $0 / 15(0 \%)$ & $4 / 15(26.7 \%)$ & $3 / 15$ (20\%) & $0 / 15(0 \%)$ & $0 / 15(0 \%)$ & $0 / 15(0 \%)$ \\
\hline 8 & $0 / 15(0 \%)$ & $0 / 15(0 \%)$ & $0 / 15(0 \%)$ & 1/15 (6.7\%) & 0/15 (0\%) & $0 / 15(0 \%)$ & $0 / 15(0 \%)$ & $1 / 15(6.7 \%)$ \\
\hline 12 & $0 / 15(0 \%)$ & $0 / 15(0 \%)$ & $0 / 15(0 \%)$ & $1 / 15(6.7 \%)$ & $0 / 15(0 \%)$ & $0 / 15(0 \%)$ & $0 / 15(0 \%)$ & $0 / 15(0 \%)$ \\
\hline 24 & $3 / 15$ (20\%) & $3 / 15(10 \%)$ & $0 / 15(0 \%)$ & $0 / 15(0 \%)$ & $0 / 15(0 \%)$ & $0 / 15(0 \%)$ & $0 / 15(0 \%)$ & $0 / 15(0 \%)$ \\
\hline$\geq 32$ & $2 / 15(13.3 \%)$ & $2 / 15$ (13.3\%) & $11 / 15(73.3 \%)$ & $0 / 15(0 \%)$ & $0 / 15(0 \%)$ & $0 / 15(0 \%)$ & $0 / 15(0 \%)$ & $0 / 15(0 \%)$ \\
\hline$\geq 256$ & $0 / 15(0 \%)$ & $0 / 15(0 \%)$ & $0 / 15(0 \%)$ & $0 / 15(0 \%)$ & $3 / 15$ (20\%) & $0 / 15(0 \%)$ & $0 / 15(0 \%)$ & $0 / 15(0 \%)$ \\
\hline Total of & $10 / 15(66,7 \%)$ & $0 / 15(0 \%)$ & $3 / 15(20 \%)$ & $9 / 15(60 \%)$ & $12 / 15(80 \%)$ & $15 / 15(100 \%)$ & $15 / 15(100 \%)$ & $14 / 15(93,3 \%)$ \\
\hline
\end{tabular}
strains*

Clo $=$ chloramphenicol, Mox $=$ moxifloxacin, $\mathrm{Ofx}=$ ofloxacin, $\mathrm{Tob}=$ tobramycin; ${ }^{*}$ criteria established based on serum concentrations.

Table 4. Percentage agreement of results from E-test and disk-diffusion (DD) tests, and estimates of the Kappa coefficients of agreement

\begin{tabular}{ccccc}
\hline Comparison & \% agreement & Kappa & p & Interpretation \\
\hline Tob (E-test x DD) & $70.0 \%$ & 0.3284 & 0.0263 & Weak \\
Clo (E-test x DD) & $93.4 \%$ & 0.8421 & $<0.0001$ & Excellent \\
Ofx (E-test x DD) & $86.7 \%$ & 0.7368 & $<0.0001$ & Good
\end{tabular}

$\overline{\mathrm{Tob}}=$ tobramycin, $\mathrm{Clo}=$ chloramphenicol, Ofx $=$ ofloxacin. 
manipulated compounded ophthalmic solutions containing only these antimicrobials were administered (5\% cefazolin, $5 \%$ vancomycin and 10,000 U/mL polymyxin B eye drops, Laboratory Ophthalmos, São Paulo, Brazil). In 100\% of the treated animals, signs of ocular infection were resolved after 15 days of treatment ( 1 drop in both eyes four times daily).

\section{DISCUSSION}

The high percentage of dogs with keratoconjunctivitis sicca with positive cultures $(90.8 \%)$ compared with that in the control group (36.7\%) reinforces the importance of identifying the profile and susceptibility of bacterial agents to guide antibiotic treatment (Prado et al. 2006, Ledbetter et al. 2009, Oria et al. 2013, LoPinto et al. 2015). Although the control and KCS groups had different origins (kennel x tutor), we assume that the substantially high difference in the proportions of positivity between these groups may be more related to changes in the ocular microenvironment in dogs with KCS than in the environment of the animals. Considering that the antimicrobial susceptibility profile of gram-positive bacteria differs from that of gram-negative bacteria, definitive identification of the microbial agent by bacteriological culture or presumptive identification by ocular secretion cytology is crucial to guide antimicrobial therapy. In addition, more than $50 \%$ of the results of the microbiological cultures were discordant between the left and right eyes in the animals in our study, reinforcing the need for bilateral culture to identify the agents associated with infections. Overall, our results support the recommendation of avoiding empirical therapy without auxiliary laboratory tests (Murray et al. 2015, Gould \& Papasouliotis 2013).

In our study, the pathogen with the highest prevalence in the eyes of the animals was SIG, which was isolated from approximately $67 \%$ of the samples investigated. For SIG, Staphylococcus pseudintermedius is the principal species of coagulase-positive, gram-positive commensal coccus found in the skin and mucous membranes of dogs and commonly colonizes the eyes of healthy dogs (Prado et al. 2006, Lin \& Petersen-Jones 2007, Oria et al. 2013, LoPinto et al. 2015) as well as the eyes of dogs with corneal ulceration (Wang et al. 2008). In contrast gram-negative bacteria were isolated from at least one eye in $40 \%(26 / 65)$ of the dogs with keratoconjunctivitis sicca in our study. These results suggest that both gram- and gram-negative bacterial agents play an important role as opportunist pathogens in the conjunctival mucosa of dogs with KCS. In dog eyes, gram-positive cocci and non-fermenting glucose rods typically colonize mucosal and cutaneous sites, whereas gram-negative enteric rods likely originate from environmental contamination, constituting a transient microbiota in the eyes (Armstrong 2000, Wang et al. 2008).

The prevalence of SIG strains in the animals of this study is consistent with other studies in Brazil on the profile of microorganisms associated with canine corneal ulcer infections (Prado et al. 2006, Monteiro et al. 2018), which suggests that this group is equally important in secondary ocular infections in dogs with KCS. The second most common group of microorganisms was Streptococcus sp. (non-hemolytic), which likely has an uncertain significance in the genesis and perpetuation of ocular infections secondary to keratoconjunctivitis sicca because Streptococcus is less virulent than is beta-hemolytic Streptococcus, which is recognized as more relevant (Hindley et al. 2016). Second-generation fluoroquinolones, especially ciprofloxacin and ofloxacin, are commonly indicated for the treatment of ophthalmic infections in dogs, presumably because of their broad spectrum and good action against severe eye infections (Maggs 2008). Regardless, compared to tobramycin and chloramphenicol, we found low sensitivity to these drugs among the SIG strains in this study. This finding suggests that aminoglycosides and chloramphenicol may be more suitable for empirical or prophylactic treatment of ophthalmic infections in dogs compared with quinolones, such as ciprofloxacin, moxifloxacin and gatifloxacin, with a consistently reduced therapeutic efficacy due to increasing resistance rates observed in the last decade (Chawla et al. 2010, Hsu et al. 2013). In view of this, it is suggested that the use of fluoroquinolones, particularly second-generation agents, alone as monotherapy should be discouraged as treatment for eye infections in dogs with KCS, unless the results of eye-tracking smear cytology exclude gram-positive cocci, similar to the recommendations of other studies (Hindley et al. 2016). The isolates in the present study were highly susceptible to polymyxin B and chloramphenicol, which is consistent with the findings reported by other authors. Chloramphenicol is a broad-spectrum antibiotic that has been widely used since the emergence of methicillin-resistant staphylococci. However, the use of this drug in humans has been limited due to its toxic effects (Short et al. 2014, Mouney et al. 2015, Ruzauskas et al. 2015).

SIG strains resistant to nine or more antimicrobials were isolated from three dogs. Two isolates were resistant to oxacillin, an antimicrobial considered to be important as a marker of multi-drug resistance in human ocular infections (Hsu et al. 2013). Other authors have also reported increased resistance of SIG strains in canine ocular infections (Tajima et al. 2013, Kang et al. 2014a, 2014b). However, the isolates exhibited low susceptibility to tetracycline, with only $40.2 \%$ of the isolates being susceptible to this antibiotic. This result is consistent with previous findings reporting resistance to tetracycline in greater than $50 \%$ of SIG strains isolated from individuals with ophthalmic diseases (Chandler et al. 2010).

Susceptibility testing of the isolates using interpretive criteria of the E-test method revealed that tobramycin exhibits good effectiveness against both gram-negative and gram-positive bacteria, such as SIG strains. This finding is consistent with the results of others (Kang et al. 2014a). According to the E-test, the quinolones tested demonstrated low effectiveness against SIG strains, with resistance rates greater than $80 \%$. Considering that moxifloxacin and ofloxacin have recently frequently been used clinically for the treatment of canine ophthalmopathies, our results point to the possible emergence of resistant strains among animals in the region of Presidente Prudente/SP, Brazil, in a manner similar to other regions of the world (Kang et al. 2014b, Moodley et al. 2014).

In contrast, gram-negative bacteria were found to be susceptible to the quinolones tested, suggesting that the selection pressure on these microorganisms is reduced compared with that observed for SIG strains. However, multi-drug-resistant E. coli strains commonly observed in urinary infections are exceptions to this finding (Cummings et al. 2015).

Given that our criteria for interpreting the results of antimicrobial tests were based on the guidelines used 
for systemic antibiotics (CLSI 2017) and that the topical antimicrobial concentration generally exceeds the systemic concentration, it is possible that the results regarding susceptibility and resistance may be associated with a tendency toward underestimation of the real therapeutic efficacy of these antimicrobials. Nonetheless, some human studies have recommended the use of interpretation criteria for systemic doses of antimicrobials to guide topical therapy due to the relationship between in vitro sensitivity and clinical recovery of treated patients (Parmar et al. 2006, Chen et al. 2008). Thus, criteria based on systemic doses of antimicrobials are the least reasonable option when determining topical therapy in ocular infections.

\section{CONCLUSIONS}

Based on our results, bacterial species isolated from the eyes of dogs with keratoconjunctivitis sicca exhibit variable susceptibility to the various antibiotics tested.

The high frequency of quinolone-resistant strains of SIG isolates found at a high prevalence in the eyes of these animals reinforces the need to identify the antimicrobial susceptibility profile of the bacteria involved, as secondary infections can be an exacerbating and perpetuating factor in KCS.

Acknowledgments.- The authors would like to thank the Graduate Studies Program of Unoeste for financial support.

Conflict of interest statement.- The authors declare that there is no conflict of interest.

\section{REFERENCES}

Ahn M., Yoon K.C., Ryu S.K., Cho N.C. \& You I.C. 2011. Clinical aspects and prognosis of mixed microbial (bacterial and fungal) keratitis. Cornea 30(4):409-413. <http://dx.doi.org/10.1097/IC0.0b013e3181f23704> $<$ PMid:21045645>

Andrade A.L., Stringhini G., Bonello F.L., Marinho M. \& Perri S.H.V. 2002. Microbiota conjuntival de cães sadios da cidade de Araçatuba (SP). Arq. Bras. Oftalmol. 65(3):323-326. <http://dx.doi.org/10.1590/S000427492002000300008>

Andrews J.M. 2001. Determination of minimum inhibitory concentrations. J. Antimicrob. Chemother. 48(Suppl.1):5-16. <http://dx.doi.org/10.1093/ jac/48.suppl_1.5><PMid:11420333>

Armstrong R.A. 2000. The microbiology of the eye. Ophthalmol. Physiol. Optics. 20(6):429-441. <http://dx.doi.org/10.1111/j.1475-1313.2000. tb01121.x><PMid:11127123>

Carter R. \& Colitz C.M.H. 2002. The causes, diagnosis and treatment of canine keratoconjunctivitis sicca. Vet. Med. 97(9):683-694.

Chandler H.L., Gemensky-Metzler A.J., Bras I.D., Robbin-Webb T.E., Saville W.J. \& Colitz C.M. 2010. In vivo effects of adjunctive tetracycline treatment on refractory corneal ulcers in dogs. J. Am. Vet. Med. Assoc. 237(4):378386. <http://dx.doi.org/10.2460/javma.237.4.378><PMid:20707747>

Chawla B., Agarwal P., Tandon R., Titiyal J.S., Sharma N., Agarwal T., Navak N. \& Satpathy G. 2010. In vitro susceptibility of bacterial keratitis isolates to fourth-generation fluoroquinolones. Eur. J. Ophthalmol. 20(2):300-305. <http://dx.doi.org/10.1177/112067211002000207><PMid:19924668>

Chen A., Prajna L., Srinivasan M., Mahalakshmi R., Whitcher J.P., McLeod S., Lietman T.M. \& Acharya N.R. 2008. Does in vitro susceptibility predict clinical outcome in bacterial keratitis? Am. J. Ophthalmol. 145(3):409412. <http://dx.doi.org/10.1016/j.ajo.2007.11.004> <PMid:18207124>
CLSI 2017. CLSI supplement M100. Performance Standards for Antimicrobial Susceptibility Testing. 27th ed. Clinical and Laboratory Standards Institute, Wayne, PA.

Cummings K.J., Aprea V.A. \& Altier C. 2015. Antimicrobial resistance trends among canine Escherichia coli isolates obtained from clinical samples in the northeastern USA, 2004-2011. Can. Vet.J. 56(4):393-398. <PMid:25829560>

Giuliano E.A. 2013. Diseases and surgery of canine lacrimal secretory system, p.912-944. In: Gelat K.N., Gilger B.C. \& Kern T.J. (Eds), Veterinary Ophthalmology. 5th ed. Wiley-Blackwell, Iowa.

Gould D. \& Papasouliotis K. 2013. Clinical microbiology and parasitology, p.300350. In: Gelat K.N., Gilger B.C. \& Kern T.J. (Eds), Veterinary Ophthalmology. 5 th ed. Wiley-Blackwell, Iowa.

Hendrix D.V.H. \& Cox S.K. 2008. Pharmacokinetics of topically applied ciprofloxacin in tears of mesocephalic and brachycephalic dogs. Vet. Ophthalmol.11(1):7-10.<http://dx.doi.org/10.1111/j.1463-5224.2007.00591. $\mathrm{x}><$ PMid:18190345>

Hindley K.E., Groth A.D., King M., Graham K. \& Billson F.M. 2016. Bacterial isolates, antimicrobial susceptibility, and clinical characteristics of bacterial keratitis in dogs presenting to referral practice in Australia. Vet. Ophthalmol. 19(5):418-426. <http://dx.doi.org/10.1111/vop.12325><PMid:26522379>

Hsu H.Y., Lind J.T., Tseng L. \& Miller D. 2013. Ocular flora and their antibiotic resistance patterns in the midwest: a prospective study of patients undergoing cataract surgery. Am. J. Ophthalmol. 155(1):36-44. <http:// dx.doi.org/10.1016/j.ajo.2012.06.024 ><PMid:22995030>

Kang M.H., Chae M.J., Yoon J.W., Kim S.G., Lee S.Y., Yoo J.H. \& Park H.M. 2014a. Antibiotic resistance and molecular characterization of ophthalmic Staphylococcus pseudintermedius isolates from dogs. J. Vet. Sci. 15(3):409415. <http://dx.doi.org/10.4142/jvs.2014.15.3.409><PMid:24690601>

Kang M.H., Chae M.J., Yoon J.W., Lee S.Y., Yoo J.H. \& Park H.M. 2014b. Resistance to fluoroquinolones and methicillin in ophthalmic isolates of Staphylococcus pseudintermedius from companion animals. Can. Vet. J. 55(7):678-682. <PMid:24982521>

Kaye S., Tuft S., Neal T., Tole D., Leeming J., Figueiredo F., Armstrong M., McDonnell P., Tullo A. \& Parry C. 2010. Bacterial susceptibility to topical antimicrobials and clinical outcome in bacterial keratitis. Invest. Opthalmol. Visual Sci. 51(1):362-368. <http://dx.doi.org/10.1167/iovs.09-3933> <PMid:19684005>

Lalitha P., Srinivasan M., Manikandan P., Bharathi M.J., Rajaraman R., Ravindran M., Cevallos V., Oldenburg C.E., Ray K.J., Toutain-Kidd C.M., Glidden D.V., Zegans M.E., McLeod S.D., Acharya N.R. \& Lietman T.M. 2012. Relationship of in vitro susceptibility to moxifloxacin and in vivo clinical outcome in bacterial keratitis. Clin. Infect. Dis. 54(10):1381-1387. <http://dx.doi. org/10.1093/cid/cis189><PMid:22447793>

Ledbetter E.C., Mun J.J., Kowbel D. \& Fleiszig S.M. 2009. Pathogenic phenotype and genotype of Pseudomonas aeruginosa isolates from spontaneous canine ocular infections. Invest. Ophthalmol. Visual Sci. 50(2):729-736. <http:// dx.doi.org/10.1167/iovs.08-2358><PMid:18836164>

Leigue L., Montiani-Ferreira F. \& Moore B.A. 2016. Antimicrobial susceptibility and minimal inhibitory concentration of Pseudomonas aeruginosa isolated from septic ocular surface disease in different animal species. Open Vet. J. 6(3):215-222. <http://dx.doi.org/10.4314/ovj.v6i3.9><PMid:27928519>

Lin C.T. \& Petersen-Jones S.M. 2007. Antibiotic susceptibility of bacterial isolates from corneal ulcers of dogs in Taiwan. J. Small Anim. Pract. 48(5):271-274. <http://dx.doi.org/10.1111/j.1748-5827.2007.00348. $\mathrm{x}><$ PMid:17425695>

LoPinto A.J., Mohammed H.O. \& Ledbetter E.C. 2015. Prevalence and risk factors for isolation of methicillin-resistant Staphylococcus in dogs with keratitis. Vet. Ophthalmol. 18(4):297-303. <http://dx.doi.org/10.1111/ vop.12200><PMid:25130050>

Maggs D.J. 2008. Basic diagnostic techniques, p.81-106. In: Maggs D.J., Miller P.E. \& Ofri R. (Eds), Slatter's Fundamentals of Veterinary Ophthalmology. 
4th ed. Saunders Elsevier, St Louis. <http://dx.doi.org/10.1016/B978072160561-6.50008-3>.

Mališová L., Šafránková R., Kekláková J., Petráš P., Žemličková H. \& Jakubů V. 2019. Correct species identification (reclassification in CNCTC) of strains of Staphylococcus intermedius-group can improve an insight into their evolutionary history. Folia Microbiol., Praha 64(2):231-236. <http://dx.doi. org/10.1007/s12223-018-0647-7><PMid:30238302>

Mannis M.J. \& Smolin G. 1996. Natural defense mechanisms of the ocular surface, p.185-190. In: Pepose J.S., Holland G.N. \& Wilhelmeus K.R. (Eds), Ocular Infection and Immunity. Mosby, St Louis.

McGinnigle S., Naroo S.A. \& Eperjesi F. 2012. Evaluation of dry eye. Survey Ophthalmol. 57(4):293-316. <http://dx.doi.org/10.1016/j. survophthal.2011.11.003><PMid:22726587>

Mello E.S., Voget V., Roncatti F.T.L.B. \& Teixeira A.L. 2017. Retrospective study: prevalence of bacterial resistance to moxifloxacin and ciprofloxacin in corneal ulcers of dogs in São Paulo, Brazil, from 2012 to 2015. Proceedings of the Annual Scientific Meeting, European College of Veterinary Ophthalmologists (ECVO), Estoril, Portugal, p.142. (Resumo)

Messmer E.M. 2015. The pathophysiology, diagnosis, and treatment of dry eye disease. Dtsch. Arztebl. Int. 112(5):71-82.<http://dx.doi.org/10.3238/ arztebl.2015.0071><PMid:25686388>

Miller P.E. 2008. Lacrimal system, p.157-174. In: Maggs D.J., Miller P.E. \& Ofri R. (Eds), Slatter's Fundamentals of Veterinary Ophthalmology. 4th ed. Saunders Elsevier, St Louis. <http://dx.doi.org/10.1016/B978072160561-6.50012-5>

Moodley A., Damborg P. \& Nielsen S.S. 2014. Antimicrobial resistance in methicillin susceptible and methicillin resistant Staphylococcus pseudintermedius of canine origin: literature review from 1980 to 2013. Vet. Microbiol. 171(3/4):337-341. <http://dx.doi.org/10.1016/j.vetmic.2014.02.008> <PMid:24613081>

Monteiro G.B., Ruiz T., Schroder D.C., Silveira M.M., Dower N.M.B., Kagueyama F., Dutra V. \& Ribeiro A.P. 2018. Susceptibilidade antibiótica de isolados bacterianos em diferentes tipos de ceratites ulcerativas de cães na cidade de Cuiabá. Pesq. Vet. Bras. 38(4):726-733. <http://dx.doi.org/10.1590/16785150-pvb-4906>

Mouney M.C., Stiles J., Townsend W.M., Guptill L. \& Weese J.S. 2015. Prevalence of methicillin-resistant Staphylococcus spp. in the conjunctival sac of healthy dogs. Vet. Ophthalmol.18(2):123-126.<http://dx.doi.org/10.1111/ vop.12130><PMid:24299189>

Murphy J.M., Lavach J.D. \& Severin G.A. 1978. Survey of conjunctival flora in dogs with clinical signs of external eye disease. J. Am. Vet. Med. Assoc. 172(1):8-66. <PMid:624664>

Murray P.R., Rosenthal K.S. \& Pfaller M.A. 2015. Medical Microbiology. 8th ed. Elsevier, Philadelphia, p.122-201.
Oria A.P., Pinna M.H., Furtado M.A., Pinheiro A.C.O., Gomes Junior D.C. \& Costa Neto J.M. 2013. Microbiota conjuntival em cães clinicamente sadios e cães com ceratoconjuntivite seca. Ciênc. Anim. Bras. 14(4):495-500. <http:// dx.doi.org/10.5216/cab.v14i4.19210>

Parmar P., Salman A., Kalavathy C.M., Kaliamurthy J., Prasanth D.A., Thomas P.A. \& Jesudasan C.A. 2006. Comparison of topical gatifloxacin $0.3 \%$ and ciprofloxacin $0.3 \%$ for the treatment of bacterial keratitis. Am. J. Ophthalmol. 141(2):282-286. <http://dx.doi.org/10.1016/j.ajo.2005.08.081> $<$ PMid:16458681>

Prado M.R., Rocha M.F.G., Brito E.H.S., Girão M.D., Monteiro A.J., Teixeira M.F. \& Sidrim J.J.C. 2005. Survey of bacterial microorganisms in the conjuntival sac of clinically normal dogs and dogs with ulcerative keratitis in Fortaleza, Ceará, Brazil. Vet. Ophthalmol. 8(1):33-37. <http://dx.doi. org/10.1111/j.1463-5224.2005.04061.x><PMid:15644098>

Prado M.R., Brito E.H.S., Girão M.D., Sidrim J.J.C. \& Rocha M.F.G. 2006 Identification and antimicrobial susceptibility of bacteria isolated from corneal ulcers of dogs. Arq. Bras. Med. Vet. Zootec. 58(6):1024-1029. <http://dx.doi.org/10.1590/S0102-09352006000600008>

Quinn P.J., Markey B.K., Leonard F.C., Hartigan P. \& Fanning S. 2011. Veterinary Microbiology and Microbial Disease. Wiley-Blackwell, New Jersey, p.149-197.

Ruzauskas M., Couto N., Kerziene S., Siugzdiniene R., Klimiene I., Virgailis M. \& Pomba C. 2015. Prevalence, species distribution and antimicrobial resistance patterns of methicillin-resistant staphylococci in Lithuanian pet animals. Acta Vet. Scand. 2(57):1-7. <http://dx.doi.org/10.1186/ s13028-015-0117-z><PMid:26032539>

Short J., Zabel S., Cook C. \& Schmeitzel L. 2014. Adverse events associated with chloramphenicol use in dogs: a retrospective study (2007-2013). Vet. Rec. 175(21):537. <http://dx.doi.org/10.1136/vr.102687><PMid:25096589>

Stevenson W., Chauhan S.K. \& Dana R. 2012. Dry eye disease: an immunemediated ocular surface disorder. Arch. Ophthalmol. 130(1):90-100. <http://dx.doi.org/10.1001/archophthalmol.2011.364><PMid:22232476>

Tajima K., Sinjyo A., Ito T., Noda Y., Goto H. \& Ito N. 2013. Methicillin-resistant Staphylococcus aureus keratitis in a dog. Vet. Ophthalmol. 16(3):240-243. <http://dx.doi.org/10.1111/j.1463-5224.2012.01066.x><PMid:23127159>

Wang L., Pan Q., Zhang L., Xue Q., Cui J. \& Qi C. 2008. Investigation of bacterial microorganisms in the conjunctival sac of clinically normal dogs and dogs with ulcerative keratitis in Beijing, China. Vet. Ophthalmol.11(3):145-149. <http://dx.doi.org/10.1111/j.1463-5224.2008.00579.x><PMid:18435654>

Wilkie D.A. 1996. Management of keratoconjunctivitis sicca in dogs, p.234238. In: Glaze M.B. (Ed.), The Compendium Collection: ophthalmology in small animal practice. 2nd ed. Veterinary Learning Systems, New Jersey.

Williams D.L. 2008. Immunopathogenesis of keratoconjunctivitis sicca in the dog. Vet. Clin. N. Am., Small Anim. Pract. 38(2):251-268, vi. <http:// dx.doi.org/10.1016/j.cvsm.2007.12.002 ><PMid:18299006> 